\title{
PEG- and Peptide-Grafted Aliphatic Polyesters by \\ Click Chemistry
}

\author{
Bryan Parrish, Rebecca B. Breitenkamp, and Todd Emrick ${ }^{*}$ \\ Supporting Information
}

Synthesis of $\alpha$-propargyl- $\delta$-valerolactone (1). $n$-Butyllithium ( $42.5 \mathrm{~mL}, 93.5 \mathrm{mmol})$ was added by syringe to a solution of $\mathrm{N}, \mathrm{N}$-diisopropylamine $(13.1 \mathrm{~mL}, 93.5 \mathrm{mmol})$ in $625 \mathrm{~mL}$ THF at $-78{ }^{\circ} \mathrm{C}$ and stirred for $15 \mathrm{~min}$. A solution of $\delta$-valerolactone $(8.51 \mathrm{~g}, 85.0 \mathrm{mmol})$ in $225 \mathrm{~mL}$ THF was added dropwise over $1.5 \mathrm{~h}$ and then stirred for an additional $30 \mathrm{~min}$. Propargyl bromide $(11.4 \mathrm{~mL}, 102 \mathrm{mmol})$ and hexamethylphosphoramide $(17.7 \mathrm{~mL}, 102 \mathrm{mmol})$ were added dropwise over $20 \mathrm{~min}$. The reaction mixture was then warmed to approximately $-30{ }^{\circ} \mathrm{C}$, and the temperature was maintained while stirring for $2 \mathrm{~h}$. Excess aqueous ammonium chloride was added, and the reaction mixture was allowed to warm to room temperature. Volatiles were removed by rotary evaporation. The resulting product was dissolved in ether, washed with a saturated $\mathrm{NaCl}$ aqueous solution, diluted with hexanes, washed again with the $\mathrm{NaCl}$ solution, dried over $\mathrm{MgSO}_{4}$, and concentrated. Column chromatography (gradient 0-30\% EtOAc in hexanes) on silica gel followed by Kugelrohr distillation afforded $\mathbf{1}$ as a colorless, viscous liquid (8.68 g, 74\% yield). HRMS-EI (m/z): $[\mathrm{M}+\mathrm{H}]^{+}$calculated for $\mathrm{C}_{8} \mathrm{H}_{11} \mathrm{O}_{2}$ 139.076, found 139.078. ${ }^{1} \mathrm{H}$ NMR $\left(\mathrm{CDCl}_{3}, 300 \mathrm{MHz}\right): \quad \delta\left(\mathrm{CHCl}_{3}=7.26 \mathrm{ppm}\right) 4.28\left(\mathrm{~m}, 2 \mathrm{H}, \mathrm{CH}_{2} \mathrm{O}\right), 2.62(\mathrm{~m}, 2 \mathrm{H}$, 
$\left.\mathrm{COCHCH}_{2}\right), 2.46\left(\mathrm{~m}, 1 \mathrm{H}, \mathrm{COCHCH}_{2}\right), 2.22\left(\mathrm{sxt}, J=6.4 \mathrm{~Hz}, 1 \mathrm{H}, \mathrm{CHCH}_{2} \mathrm{CH} 2\right), 1.97(\mathrm{t}-\mathrm{d}, J=2.7$ $\mathrm{Hz} J=1.0 \mathrm{~Hz}, 1 \mathrm{H}, \mathrm{C} \equiv \mathrm{CH}), 1.89\left(\mathrm{q}, J=6.3 \mathrm{~Hz}, 2 \mathrm{H}, \mathrm{CH}_{2} \mathrm{CH}_{2} \mathrm{CH}_{2}\right), 1.68\left(\mathrm{~m}, 1 \mathrm{H}, \mathrm{COCHCH}_{2}\right)$ ppm. ${ }^{13} \mathrm{C} \mathrm{NMR}\left(\mathrm{CDCl}_{3}, 75 \mathrm{MHz}\right): \quad \delta\left(\mathrm{CHCl}_{3}=77.0 \mathrm{ppm}\right) 172.8(\mathrm{C}=\mathrm{O}), 81.1(\mathrm{C} \equiv \mathrm{CH}), 70.4$ $\left(\mathrm{CH}_{2} \mathrm{O}\right), 68.8(\mathrm{CH} \equiv \mathrm{C}), 38.9(\mathrm{CC}=\mathrm{O}), 24.1\left(\mathrm{CCH}_{2} \mathrm{CH}_{2}\right), 22.0\left(\mathrm{CCH}_{2} \mathrm{CH}_{2}\right), 20.7\left(\mathrm{CH}_{2} \mathrm{C} \equiv \mathrm{CH}\right)$ ppm. IR(ATR): C $\equiv \mathrm{C}-\mathrm{H} 3280, \mathrm{C}=\mathrm{O} 1724 \mathrm{~cm}^{-1}$.

Synthesis of PEG-1100 monomethyl ether azide (3). PEG-1100 monomethyl ether (10.0 g, $9.09 \mathrm{mmol})$ and triethylamine $(1.5 \mathrm{~mL}, 10 \mathrm{mmol})$ were dissolved in THF $(50 \mathrm{~mL})$ and cooled to $0{ }^{\circ} \mathrm{C}$. Methanesulfonyl chloride $(0.81 \mathrm{~mL}, 10.5 \mathrm{mmol})$ was added dropwise. The reaction mixture was allowed to warm to room temperature and stirred overnight. Solvent was removed by rotary evaporation, and the reaction mixture was dissolved in $95 \% \mathrm{EtOH}(50 \mathrm{~mL})$. Sodium azide (770 mg, $12 \mathrm{mmol}$ ) was added, and the reaction mixture was refluxed overnight. After cooling to room temperature and removing the solvent by rotary evaporation, the crude reaction mixture was dissolved in ether and washed three times with a saturated $\mathrm{NaCl}$ aqueous solution. The organic layer was then dried over $\mathrm{MgSO}_{4}$ and concentrated in vacuo to give $\mathbf{3}$ as an offwhite crystalline solid $(9.10 \mathrm{~g}, 89 \%$ yield $)$. GPC $(\mathrm{THF}): \mathrm{M}_{\mathrm{n}}=1.2 \times 10^{3} \mathrm{~g} / \mathrm{mol}, \mathrm{PDI}=1.05 .{ }^{1} \mathrm{H}$ NMR $\left(\mathrm{CDCl}_{3}, 300 \mathrm{MHz}\right): \delta\left(\mathrm{CHCl}_{3}=7.26 \mathrm{ppm}\right) 3.64\left(\mathrm{~m}, 96 \mathrm{H}, \mathrm{CH}_{2} \mathrm{CH}_{2} \mathrm{O}\right) 3.38\left(\mathrm{~s}, 3 \mathrm{H}, \mathrm{CH}_{3}\right)$ ppm. ${ }^{13} \mathrm{C} \mathrm{NMR}\left(\mathrm{CDCl}_{3}, 75 \mathrm{MHz}\right): \delta\left(\mathrm{CHCl}_{3}=77.0 \mathrm{ppm}\right) 71.9\left(\mathrm{CH}_{2} \mathrm{OCH}_{3}\right), 70.6\left(\mathrm{CH}_{2} \mathrm{CH} \mathrm{H}_{2} \mathrm{O}\right)$, $70.0\left(\mathrm{CH}_{2} \mathrm{CH}_{2} \mathrm{OCH}_{3}\right), 59.0\left(\mathrm{CH}_{3}\right), 50.6\left(\mathrm{CH}_{2} \mathrm{~N}_{3}\right) \mathrm{ppm}$. IR(ATR): $\mathrm{N}=\mathrm{N}=\mathrm{N} 2105 \mathrm{~cm}^{-1}$.

Synthesis of bromide-terminated GRGDS (5). The oligopeptide sequence GRGDS was synthesized according to standard Fmoc solid phase peptide synthesis using the batchwise process and the peptide coupling agent HBTU. Fmoc-Ser(But)-loaded Wang resin (3.12 g with 
loading density of $0.6 \mathrm{mmol} / \mathrm{g}$ ) was weighed into an oven-dried glass-fritted reaction tube and swollen with $30 \mathrm{~mL}$ dry $\mathrm{CH}_{2} \mathrm{Cl}_{2}$ for 5-10 min. The Fmoc group was cleaved by the addition of a 25/75 solution of piperidine/DMF ( $30 \mathrm{~mL}$ ), followed by agitation with $\mathrm{N}_{2(\mathrm{~g})}$ for $3 \mathrm{~min}$. The resin was filtered, and fresh piperidine/DMF (30 mL) was added. After agitating for $20 \mathrm{~min}$, the resin was filtered and washed with DMF 6 times.

A solution of Fmoc-Asp(OBut)-OH (3.85 g, $9.35 \mathrm{mmol})$, HBTU (3.48 g, $9.17 \mathrm{mmol})$, and HOBt (1.26 g, $9.35 \mathrm{mmol})$ in $20 \mathrm{~mL}$ of anhydrous DMF was prepared. After the solution became homogeneous, DIPEA $(3.28 \mathrm{~mL}, 18.70 \mathrm{mmol})$ was added, and the resulting mixture was added immediately to the resin. The resin was then agitated for $1 \mathrm{~h}$, filtered, and washed with DMF (3 times). A 25/75 solution of piperidine/DMF ( $30 \mathrm{~mL}$ ) was added, and the resin agitated for $3 \mathrm{~min}$. After filtration, piperidine/DMF was again added to the resin followed by agitation for 20 min. The resin was then washed with DMF (6 times). The above amino acid addition procedure was repeated for Fmoc-Gly-OH, Fmoc- $\mathrm{Arg}(\mathrm{Pbf})-\mathrm{OH}$, and a second unit of Fmoc-Gly$\mathrm{OH}$.

Following the addition of the second Gly unit, a solution of 6-bromohexanoic acid (1.82 g, $9.35 \mathrm{mmol})$ and $\mathrm{HOBt}(1.26 \mathrm{~g}, 9.35 \mathrm{mmol})$ was prepared in $15 \mathrm{~mL}$ of dry DMF. DIC (1.45 mL, $9.35 \mathrm{mmol}$ ) was added dropwise to the solution and stirred for $20 \mathrm{~min}$. The activated solution was added to the resin and agitated for $1 \mathrm{~h}$. After filtration, the resin was washed with DMF (6 times) followed by $\mathrm{CH}_{2} \mathrm{Cl}_{2}$ (4 times) to remove any residual DMF. The peptide was then deprotected and cleaved from the resin by agitating with a 88/2/5/5 solution of TFA/TIPS/ $\mathrm{H}_{2} \mathrm{O} / \mathrm{phenol}(30 \mathrm{~mL})$ for $3 \mathrm{~h}$. The solution was filtered, and the cleavage procedure was repeated with $30 \mathrm{~mL}$ of fresh solution and 30 min agitation. The resin was then washed with $\mathrm{CH}_{2} \mathrm{Cl}_{2}$ (3 times), and the filtrated was concentrated by rotary evaporation, precipitated into 
ether, and stored at $4{ }^{\circ} \mathrm{C}$ for several hours before filtration. The solid was isolated by filtration, rinsed with diethyl ether (3 times), and dried under vacuum overnight to afford $\mathbf{4}$ as a white powder in nearly quantitative yield (based upon the given resin-loading density). HRMS-FAB (m/z): $[\mathrm{M}+\mathrm{H}]^{+}$calculated for $\mathrm{C}_{23} \mathrm{H}_{39} \mathrm{~N}_{8} \mathrm{O}_{10} \mathrm{Br}$ 667.205, found 667.207. ${ }^{1} \mathrm{H}$ NMR ( $\mathrm{d}_{6}-\mathrm{DMSO}, 400$ MHz): $\delta(\mathrm{DMSO}=2.50 \mathrm{ppm}) 11.90(\mathrm{br}, 2 \mathrm{H}), 8.30(\mathrm{br}, 1 \mathrm{H}), 8.20(\mathrm{~d}, J=7.9 \mathrm{~Hz}, 1 \mathrm{H}), 8.07(\mathrm{~m}$, 2H), $7.88(\mathrm{~d}, J=7.7 \mathrm{~Hz}, 1 \mathrm{H}), 7.72(\mathrm{br}, 1 \mathrm{H}), 7.16(\mathrm{br}, 2 \mathrm{H}), 4.64(\mathrm{~m}, 1 \mathrm{H}), 4.22(\mathrm{~m}, 2 \mathrm{H}), 3.66(\mathrm{~m}$, $8 \mathrm{H}), 3.50(\operatorname{tr}, J=6.7 \mathrm{~Hz}, 2 \mathrm{H}), 3.07(\mathrm{~m}, 2 \mathrm{H}), 2.13(\operatorname{tr}, J=7.2 \mathrm{~Hz}, 2 \mathrm{H}), 1.78(\mathrm{~m}, 2 \mathrm{H}), 1.64(\mathrm{br}$, 2H), $1.50(\mathrm{~m}, 6 \mathrm{H}), 1.35(\mathrm{~m}, 2 \mathrm{H}) \mathrm{ppm} .{ }^{13} \mathrm{C}$ NMR $\left(\mathrm{d}_{6}-\mathrm{DMSO}, 125 \mathrm{MHz}\right): \delta(\mathrm{DMSO}=39.52$ ppm) $172.7,172.0,171.9,170.7,169.4,168.7,156.8,61.4,55.0,52.3,49.4,42.1,40.4,36.4$, 35.1, 35.0, 32.1, 29.1, 27.3, 24.9, 24.4 ppm. IR(ATR): O-H and N-H 3286.1, C-H 2937.0, C=O 1644.1, N-H $1531.9 \mathrm{~cm}^{-1}$.

Synthesis of azide-terminated GRGDS (6). Bromide-terminated GRGDS 5 (1.17 g, 1.75 mmol) was dissolved in DMSO (3.5 mL, $0.5 \mathrm{M})$, and $\mathrm{NaN}_{3}(0.13 \mathrm{~g}, 2.0 \mathrm{mmol})$ was added to the solution. The reaction was allowed to proceed for $12-18 \mathrm{~h}$ at room temperature after which the solution was filtered through Celite. Following rotary evaporation and Kugelrohr distillation to remove DMSO, the crude product was dissolved in a minimal amount of methanol, and the insoluble precipitate was removed by filtration. The remaining solution was precipitated from diethyl ether and filtered to afford azide 6 as a white powder (1.09 g, 99\% yield). HRMS-FAB (m/z): $[\mathrm{M}+\mathrm{H}]^{+}$calculated for $\mathrm{C}_{23} \mathrm{H}_{39} \mathrm{~N}_{11} \mathrm{O}_{10} 630.296$, found 630.296. ${ }^{1} \mathrm{H}$ NMR (d $\mathrm{d}_{6}$-DMSO, 400 MHz): $\delta(\mathrm{DMSO}=2.50 \mathrm{ppm}) 8.36(\mathrm{br}, 1 \mathrm{H}), 8.27(\mathrm{~m}, 2 \mathrm{H}), 8.07(\mathrm{~m}, 2 \mathrm{H}), 7.72(\mathrm{~d}, J=7.4 \mathrm{~Hz}$, 1H), $7.23(\mathrm{br}, 2 \mathrm{H}), 4.58(\mathrm{~m}, 1 \mathrm{H}), 4.23(\mathrm{~m}, 1 \mathrm{H}), 4.14(\mathrm{~m}, 1 \mathrm{H}), 3.59(\mathrm{~m}, 8 \mathrm{H}), 3.29(\mathrm{tr}, J=6.8 \mathrm{~Hz}$ 2H), $3.07(\mathrm{~m}, 2 \mathrm{H}), 2.13(\mathrm{tr}, J=7.3 \mathrm{~Hz}, 2 \mathrm{H}), 1.76(\mathrm{~m}, 2 \mathrm{H}), 1.50(\mathrm{~m}, 6 \mathrm{H}), 1.28(\mathrm{~m}, 2 \mathrm{H}) \mathrm{ppm} .{ }^{13} \mathrm{C}$ 
NMR $\left(\mathrm{d}_{6}\right.$-DMSO, $\left.125 \mathrm{MHz}\right): \delta(\mathrm{DMSO}=39.52 \mathrm{ppm})$ 173.4, 172.7, 172.6, 172.4, 170.6, 169.3, $168.8,157.2,61.8,55.3,52.4,50.6,49.7,42.5,42.0,40.5,36.8,35.0,29.4,28.1,25.8,24.7,24.5$ ppm. IR(ATR): O-H and N-H 3261, N=N=N 2097, C=O $1645 \mathrm{~cm}^{-1}$.

MEM evaluation of PEG-grafted polyesters 4a and 4b. L929 mouse fibroblasts were seeded at a density of 10,000 cells $/ \mathrm{cm}^{2}$ in 6-well polystyrene plates. After $24 \mathrm{~h}$ incubation, the medium was removed and replaced with fresh medium, and polymer samples dissolved in 300 $\mu \mathrm{L}$ phosphate buffered saline (PBS) were introduced to give a final concentration of $5 \mathrm{mg} / \mathrm{mL}$. Once the material was added, the fibroblasts were incubated for an additional $24 \mathrm{~h}$ and then observed microscopically for changes in confluence and morphology.
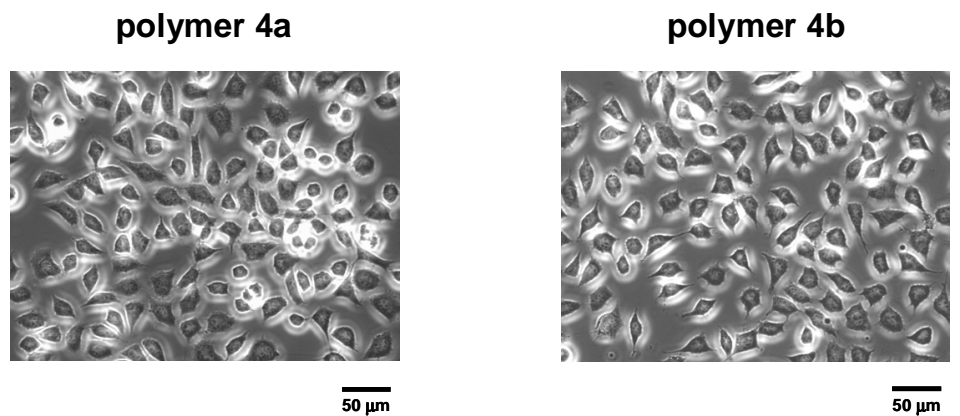